\title{
Henry Dyer Remembers: Fiji's 1985 Winter Tour of New Zealand
}

\author{
Henry Dyer Tuidraki and Kieran James* \\ *School of Business and Enterprise, University of the West of Scotland, Scotland
}

Submission: March 21, 2019; Published: April 02, 2019

*Corresponding author: Kieran James, School of Business and Enterprise, University of the West of Scotland, Scotland

\begin{abstract}
The June 1985 winter tour of New Zealand by the Fiji national soccer team was an amazing experience for the players from the developing island nation of Fiji as they were not familiar with Western standards of living or the bitter cold of a New Zealand winter. As was common in that era, the partying and drinking of the players spiraled out of control as overseas trips were very rare for ordinary Fijians in that era and players wanted to maximize the enjoyment which they could take from the tour. On-the-field, Fiji struggled to find a rhythm, and was defeated by New Zealand in all three matches, 5-0, 3-0, and 2-0. Encouragingly, the team never gave up and the losing margin was being progressively cut as the tour progressed. The tour unearthed a promising new talent, a young Muslim man from Ba called Mohd. Aiyub Bai. Although the emigration of Fiji-Indians had not yet reached its peak, there was an expatriate Fijian community in New Zealand at this time and they made every effort to make the touring team feel comfortable and at home. Henry Dyer, a member of the Fiji team, says that, with hindsight, the team lacked a strong mentor and motivator as senior player; Joe Tubuna had perished in a car-crash the previous August and Inia Bola and Semi Tabaiwalu had had their careers cut short in the same tragic accident.
\end{abstract}

Keywords: Fiji Islands; Fiji soccer; Fiji soccer history; New Zealand soccer; Pacific Islands; Soccer history

\section{Introduction}

Henry Dyer Tuidraki played for both Nadi and Lautoka in the Fiji national-league in the 1980s and represented the Fiji national team in many games, including the 1983 South Pacific Games Final in Apia, Samoa; the May 1985 3-0 win over England's Newcastle United; and the unsuccessful June 1985 winter tour of New Zealand. Henry Dyer Tuidraki presently lives in Nakavu Village, Nadi Town, Fiji Islands, where he has served as both assistant and acting village headman.

\section{Section One - Fiji's 1985 winter tour of New Zealand}

We toured New Zealand in winter 1985 but we did not do well because we were not using the European soccer pattern from Germany which we had learned from our former national team coach Rudi Gutendorf. We had a good combination of youth and seasoned players who were travelling on this tour to represent Fiji. The youth players were Ivor Evans, Akuila Rova, and this tall Muslim boy from Ba (Mohd. Aiyub Bai). The seasoned players were Savenaca Waqa, Abraham Watkins, Meli Vuilabasa, Stan Morrell, Rusiate Waqa, Sam Work, and Kelemedi "Cheetah" Vosuga. In the backs there was Stan Morrell, Abdul Manaan, and me. In the midfield there was Meli Vuilabasa, Kelemedi "Cheetah" Vosuga, and Tony Kabakoro. In the forwards there was Ivor Evans, Rusiate Waqa, and Akuila Rova. The goalkeeper was Savenaca Waqa. The reserve goalkeeper was Suka Tuba (from the since relegated Nasinu Soccer Association). This was the core of the team which I vividly remember. We had the cream of the crop there. Unfortunately, we lost all three matches. Maybe it was due to complacency and the extremely cold weather. We had to turn on the electric blankets before we went to bed. It was the first time for me to use an electric blanket and see firewood burning in a modern cement house. It was all new to me. It must have been a very new experience for most of the players and especially for the younger boys who had just joined the squad. This was the first time for me to go overseas, outside of the Pacific Islands region, to represent the nation.

We did not do too badly against the New Zealand team in the three matches even though they almost walked all over us in every game. The opening match was played at Mount Maunganui, Tauranga on June 3, 1985 in front of a crowd of 2,250 people. The second game was played at Childers Road Reserve, Gisborne on June 5, 1985 and the attendance were 1,500 people. The third and final game was played at Bill McKinlay Park in Auckland on June 7, 1985 in front of a crowd of 1,000 people. The scores were: 5-0 in the first game, 3-0 in the second game and 2-0 in the third and final game (sources: Prasad [1] Appendix VII, p. 94; Rsssf. com, $\mathrm{n} / \mathrm{d}$ ). We managed to hold them back with our individual strength in defense. We would have been thrashed badly if we had lost our composure. I learned a lot on this trip. Looking back, from the perspective of today, I believe that we had a missing ingredient within the touring party. I think it was the motivator or mentor. One factor was because the German coach Rudi 
Gutendorf had left the team. The English play pattern, which he had brought from Germany to Fiji in 1983, had been grasped by the senior players who were able to implement it with skill. In two years, in the absence of Rudi in Fiji, the attacking and the defensive patterns had faded away to the extent that most of the boys by then had adapted to a new pattern. So, it was a mix of the old and the new. I always take my hat off to the local coach, Billy Singh, for taking the Fiji soccer team through until he passed away. If there had been a senior person close to the team as a motivator or mentor, such as the late Joe Tubuna, his appearance on the field with a few words of encouragement would have made a lot of difference. Billy had played with Tubuna and so they had already developed a working partnership. The boys respected Joe as a player, a captain, and a leader. He had the art to charm the boys with his smile and his talk. He got along well with the boys. He was a very down-to-earth person. I believe that if Fiji Football Association had thought of the small things, such as taking along a motivator or mentor to psych up the team before games, the performance of the team might well have been better.

Table 1: New Zealand versus Fiji, Mount Maunganui, Tauranga, June 3, 1985.

\begin{tabular}{|c|c|}
\hline New Zealand (2) 5 & Fiji (0) 0 \\
\hline \multicolumn{2}{|l|}{$\begin{array}{c}\text { Colin Walker 30, 64, 69, Kevin Hagan } \\
\text { 33, Greg Little } 61 .\end{array}$} \\
\hline $\begin{array}{l}\text { New Zealand: Clint Gosling, Richard } \\
\text { Mulligan, Ceri Evans, Malcolm } \\
\text { Dunford, Keith Hobbs, Duncan Cole } \\
\text { [c], Kevin Hagan (Declan Edge), Colin } \\
\text { Walker, Greg Little, Peter Henry, Peter } \\
\text { Simonsen. }\end{array}$ & $\begin{array}{c}\text { Fiji: Savenaca Waqa, } \\
\text { Keverieli Salesi, Abraham } \\
\text { Watkins, Abdul Manaan, } \\
\text { Stan Morrell, Henry Dyer } \\
\text { Tuidraki, Ivor Evans, Rusiate } \\
\text { Waqa, Sam Work (Mohd. } \\
\text { Aiyub Bai), Meli Vuilabasa } \\
\text { (Kini Tubi), Kelemedi Vosuqa } \\
\text { (Akuila Rova). }\end{array}$ \\
\hline \multicolumn{2}{|l|}{ Venue: Mount Maunganui, Tauranga. } \\
\hline \multicolumn{2}{|l|}{ Referee: Gary Fleet (New Zealand). } \\
\hline \multicolumn{2}{|l|}{ Crowd: 2,250} \\
\hline Coach: Kevin Fallon. & Billy Singh. \\
\hline
\end{tabular}

I remember the first game we played at Mount Maunganui. As I said, we played our hearts out. At times we started to argue amongst ourselves. No-one knew that we were arguing because it was in the Fijian language. It was only about how to strengthen our defense and how not to take any further punishment. As often happens in Fiji soccer today, there was a lot of crowding up and no-one on the side-lines to tell us to use the flanks. There was no-one who was reading the game from outside to tell us our weaknesses and our strengths. There are two points here. There was no motivator and no strategist or technical adviser. However, during this tour, the Fijian community in New Zealand looked after the boys well. They were there to cheer the boys on during the games and they hosted the boys after the matches were finished. Today, when the national team leaves our shores, they should consider that they are taking Fiji's name and that they are going as ambassadors. They should be prepared to counter and display all aspects of the modern approach to the game. They should have a structure to their play. It would be better to have two or three patterns and then stick to those two or three patterns. Then, if the team or the squad changes, the pattern is still there. I know it will not be easy to reach this standard of preparation and performance. It will not be done overnight. It will take a period of time, perhaps three years or five years.

I hope that Fiji Football can look into these issues especially when the various national teams go on overseas tours. Our national team and the Under-20s team should both have at least two overseas tours per year. This will bring standard and composure to the players and bring the teams' games up to the modern world standard. It is a wonder that the other Pacific nations which we used to thrash, such as Solomons and Vanuatu, are now our biggest threats and continually beat us. I don't know what is happening with our performance as we play more tournaments and league matches than the other Pacific nations. We have the talent in the villages and in the rural settlements in the cane-belt areas (the western region of Viti Levu plus Labasa) to become a successful soccer nation at Oceania level and possibly beyond that. If we could beat Newcastle United, Australia, and New Zealand in the 1980s [2], I am sure that, with careful strategic planning and expert leadership, we can be close to NZ and Australia or even above them. I pray that one day maybe government or FIFA or Oceania Confederation will come in to evaluate and alleviate all aspects of the game's management and performance. When we were doing well, in the past, the rugby crowd and players used to follow us. They mingled with us very closely because in our performances we had shown ourselves to be a notch above them. Beers were given to us by the soccer crowd just like a packet of cigarettes today. You would just walk into a shop and they would give it. This is evidence of the support which existed for soccer back then, but the game was heading in the wrong direction because there were no overarching strategic plans either on-the-field or off-the-field. Today rugby may be laughing at our sport of soccer because of the placing that they have in the world rankings compared to our placing. The talent in the villages is a constant factor and can be used to play either or both sports. Therefore, rugby's success compared to soccer's must be due to superior strategic planning and management. I believe that Rajesh Patel (Fiji Football president) has the vision to put Fiji back on the soccer map (Table 1).

Unfortunately, Fiji's soccer success in the past is not widely known among the younger people. If the younger soccer fans knew about Fiji's soccer history, then it would be a source of pride and inspiration. When former star soccer players go to watch the senior games today the crowd does not seem to know them or consider them as somebody. However, they are unaware that they were the driving forces of soccer in that previous era. Soccer history largely exists in verbal form, rather than in written form, in Fiji; and this means that it can fade away as one generation disappears. Lack of interest is another factor for the 
dearth of substantial written soccer history in this country. To recap, the 1985 winter tour of New Zealand was a lesson for me personally and for Fiji soccer. Figure 1 depicts Henry Dyer Tuidraki (left) and Meli Vuilabasa, Fiji teammates on the 1985 tour, reunited in Ba Town on 2 June 2015 (Figure 1).

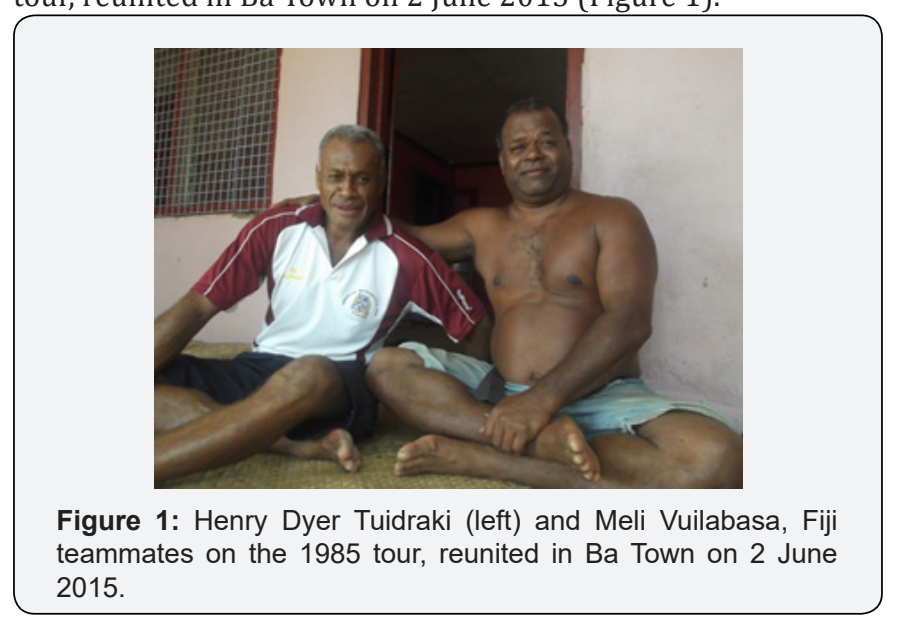

\section{Section Two - The Restaurants and Nightclubs of Old Lautoka, by Henry Dyer Tuidraki}
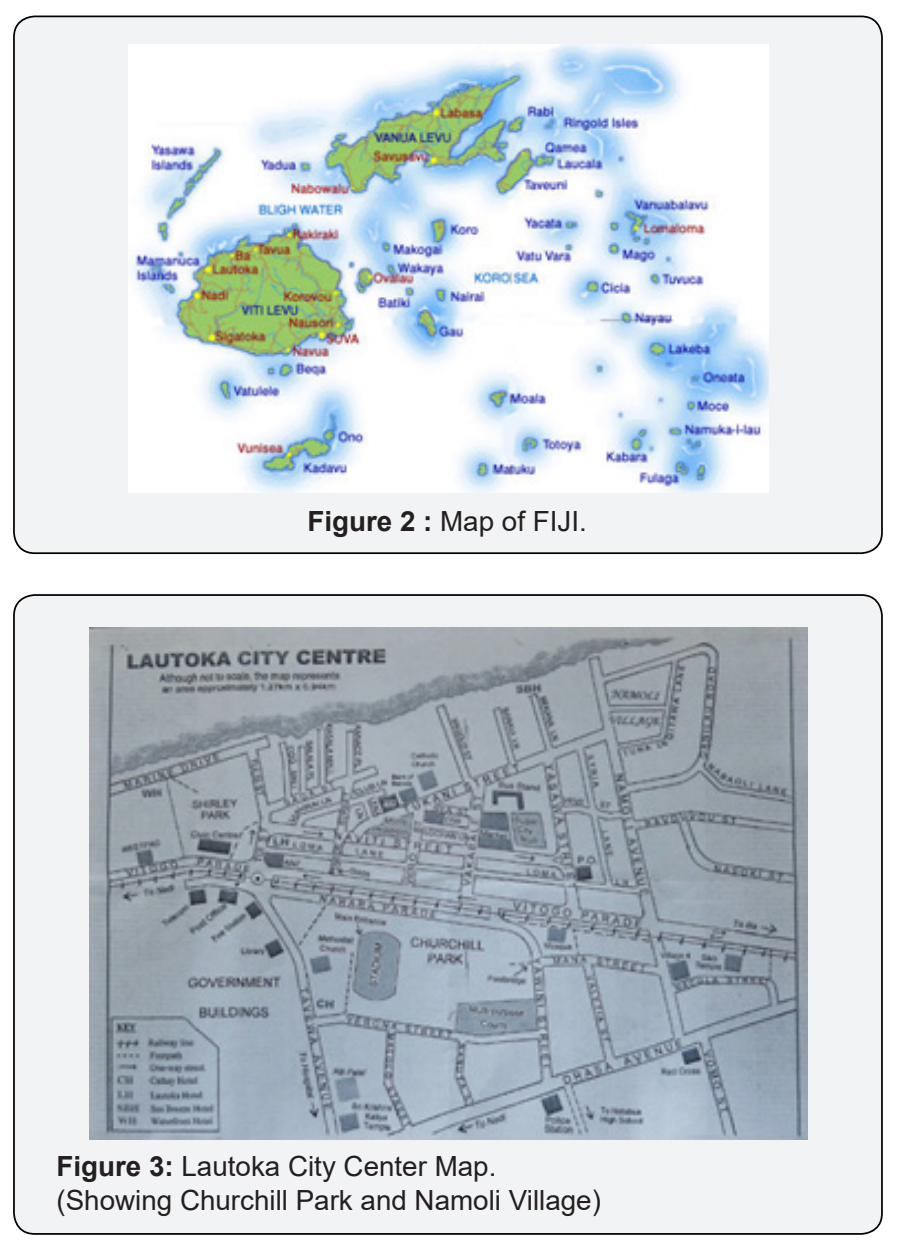

This section discusses the restaurants and nightlife of old Lautoka City, Fiji Islands, in the 1960s through to the 1990s, as recalled by the ex-Nadi and Fiji soccer champion Henry Dyer
Tuidraki in conversation with Kieran James on April 16, 2015. Lautoka has changed. Today there are new buildings as compared to the colonial buildings of the first business houses. There were only a few Chinese people before at that time. I remember Eddie Hin and Kum Poi. I was brought up with some of them then in the early-1960s through to the 1970s. We went to church with most of the Chinese community at the Evangelical Fellowship Church which was located just beside Jasper Williams High School. The church still stands today. The pastor then was Pastor Cairns. His son, Pastor Cairns Junior, took over. This is when I learned about the Chinese community at an early age as I became friends with them. One of the Chinese children (Graeme Leung) became the chairperson or president of the Law Society. Figure 2 depicts Fiji Islands with Lautoka City and Nadi Town being seen in the upperleft (north-west) quartile of the largest island Viti Levu. Figure 3 provides a map of Lautoka City Center, featuring Churchill Park, Namoli Village, Naviti Street, and Hunter's Inn Nightclub which is housed within the Lautoka Hotel compound on Tui Street (and is marked by the initials LH on the map) (Figures 2 \& 3).

Table 2: New Zealand versus Fiji, Childers Road Reserve, Gisborne, June 5, 1985.

\begin{tabular}{|c|c|}
\hline New Zealand (2) 3 & Fiji (0) 0 \\
\hline \multicolumn{2}{|l|}{$\begin{array}{c}\text { Colin Walker 32, 59, Steve } \\
\text { Sumner } 36 .\end{array}$} \\
\hline $\begin{array}{l}\text { New Zealand: Clint Gosling, } \\
\text { Richard Mulligan (Greg Little), } \\
\text { Ken Cresswell, Malcolm Dunford, } \\
\text { Keith Hobbs, Sean Byrne (Ceri } \\
\text { Evans), Peter Simonsen, Duncan } \\
\text { Cole [c] (Peter Henry), Steve } \\
\text { Sumner, Kevin Hagan (Kevin } \\
\text { Birch), Colin Walker. }\end{array}$ & $\begin{array}{l}\text { Fiji: Savenaca Waqa, Abraham } \\
\text { Watkins, Abdul Manaan, Stan } \\
\text { Morrell, Henry Dyer Tuidraki, } \\
\text { Shah (Kini Tubi), Ivor Evans, } \\
\text { Sam Work, Meli Vuilabasa, Tony } \\
\text { Kabakoro (Kelemedi Vosuqa), } \\
\text { Akuila Rova (Rusiate Waqa). }\end{array}$ \\
\hline \multicolumn{2}{|l|}{$\begin{array}{l}\text { Venue: Childers Road Reserve, } \\
\text { Gisborne. }\end{array}$} \\
\hline \multicolumn{2}{|l|}{$\begin{array}{c}\text { Referee: John Cameron (New } \\
\text { Zealand). }\end{array}$} \\
\hline \multicolumn{2}{|l|}{ Crowd: 1,500. } \\
\hline Coach: Kevin Fallon. & Billy Singh. \\
\hline
\end{tabular}

Most of the Chinese restaurateurs have moved on to different businesses. One of the restaurants then was Yang's, located beside the Globe Theater. The Globe Theater was located on the corner of Naviti Street and Vakabale Street just opposite Jolly Good Restaurant and the market. A Chinese provision and lolly shop are located there today (i.e. April 16, 2015). Yang's Restaurant was located around three stores away from Globe Theater, further down on Naviti Street (in the direction towards MH and Nan Yang Seafood Restaurant). Business in Lautoka then was very slow compared to today. Inside the Filipino tailor shop today (opposite the market on Vakabale Street) you can still see the stairway which used to lead up to the Globe Theater. The restaurant called The Great Wall of China Restaurant on Naviti Street (opposite Renee's Pub) was not open then. Those Chinese came in later although now I have heard that that family claims to be the leader of the Chinese community in Lautoka (Table 2). 
There was also the Crown Theater. It had wooden walls. It is where In fashion store is located today on Vitogo Parade. It was really old when we started going to cinemas then. I don't know for how long it had been standing before I was born in the early1960s. The third cinema was the Mayfair Theater which was located where Village 4 is today. Crown Theater closed down a long way back, years before the Globe Theater closed. This was probably due to its age. It might have been difficult to resurrect it. There were only two curry house shops in Lautoka, Narsey's and Bombay Lodge. Narsey's was located beside the Pacific Transport Headquarters which is now one of those big takeaway restaurants in Lautoka. Narsey's was located on Yasawa Street; it was about the sixth shop from the corner and opposite from the bus station. At Narsey's they had a variety of curries and they were the best in town then. I remember because, when I first worked as a dockworker at Lautoka Wharf (age 17) when I got my pay (around \$17-per-shift which was big money), I used to see the drift of the dockworkers towards this curry house. This is how and when I got my first taste of curry restaurant food in Lautoka. Today this restaurant is still there but with a different owner and a different name. Back then to have a meal away from home was like going to America and coming back. It seemed like that to me then as a child. There were other curry houses such as Bombay Lodge on Naviti Street (opposite Sugar City Mall) but Narsey's was a famous place and everyone was heading there (Table 3).

Table 3: New Zealand versus Fiji, Bill McKinlay Park, Auckland, June 7, 1985.

\begin{tabular}{|c|c|}
\hline New Zealand (1) 2 & Fiji (0) 0 \\
\hline $\begin{array}{c}\text { Steve Sumner 8 (pen), Shah 64 } \\
\text { (og). }\end{array}$ & \\
\hline $\begin{array}{c}\text { New Zealand: Frank van Hattum, } \\
\text { Richard Mulligan (William } \\
\text { McClure), Ceri Evans, Malcolm } \\
\text { Dunford, Keith Hobbs, Duncan } \\
\text { Cole [c], Peter Simonsen, Steve } \\
\begin{array}{c}\text { Sumner, Peter Henry, Greg Little } \\
\text { (Kevin Birch), Kevin Hagan. }\end{array}\end{array}$ & $\begin{array}{c}\text { Fiji: Savenaca Waqa, Abraham } \\
\text { Watkins, Stan Morrell, Kini } \\
\text { (Keverieli Salesi), Ivor Evans, } \\
\text { Rusiate Waqa (Tony Kabakoro), } \\
\text { Sam Work (Vyas), Meli Vuilabasa, } \\
\text { Kelemedi Vosuqa. }\end{array}$ \\
\hline $\begin{array}{c}\text { Venue: Bill McKinlay Park, } \\
\text { Auckland. }\end{array}$ & \\
\hline Referee: Bill Munro (New \\
Zealand).
\end{tabular}

Yang's Restaurant was the top-class restaurant in Lautoka then. They would fix the dish up with real Chinese spices. It was a top-class restaurant and not just a café or takeaway shop. There was another Chinese restaurant, Eddy Hin's. They still have this restaurant, but I don't know who the owners are now. Nan Yang Seafood Restaurant is located in the same shop too. There were only two Chinese restaurants back then. More people went to Yang's probably due to its location near to the bus station, the center of town, and the taxis. At that time the Indian community was very closely-knit. They did not mingle with the (indigenous)
Fijians much perhaps due to fear of discrimination. It was very hard to play soccer on the field with the Indian children. They had a soccer ball and you would sit on the side-lines waiting to play and they would say "no Fijians" perhaps because we were perceived to be stronger and rougher. At night you would seldom see an Indian on the street compared to nightlife today. They have opened up to this side of life much more now. The dress style of the young Indian girls today is different. Back then you would not see girls wearing tight jeans or long pants. They used to just wear Indian clothes such as saris. If you saw an Indian girl, then in long pants everyone would look at her and you would hear the passing of remarks. At that time, I am sure that the Indian population of Lautoka was significantly higher than it is today because of emigration.

There were only four nightclubs in Lautoka. The oldest of them all was Raymond's Night Club. Today it is a warehouse building connected to the wharf. It was right at the edge of the gate to the wharf. This nightclub had a balcony where you could look out towards the Bekana Island, Namoli Village, and beyond. This nightclub was the meeting-place for the local (indigenous) Fijian crowd. The owner was Raymond Wong. His son is Patrick Wong. He is one of the tourism big boys today. As at February 2007 he was the general manager of Matamanoa Island Resort and in 2009 he was Tourism Fiji chairperson. Patrick was a former boxing champion in bantamweight. We used to go to this nightclub just to see what life was like after nightfall. It used to close around 1:00 a.m. It shut down around the same time as Globe Theater or just prior to that. This would have been in the late-1970s or early-1980s. It was very similar to the atmosphere you find today at Deep Sea Nightclub in Nadi or Renee's Pub in Lautoka. People who have money take the floor and those who go to watch stand aside and wait for the chance to push their way in and take advantage of the benefits. This was just a joke to us as youth. We would sit back and watch how things worked in the nightclub. We just wanted to get a buzz before we went home. I remember I was there one night because I wanted to see what life was like in a nightclub. My uncle (Eneri Ratudradral) was a rugby player for Lautoka then. When he saw me, he said: "Hey nephew, come here." I thought he was happy to see me. This was in the nightclub. He asked me who I had come with. I said: "With my friends." Then he pulled out his belt and he said: "I want to see you go down these stairs and then run home to the village." He was referring to Namoli Village where I then lived (refer to Figure 3). This did not deter me as we had quite a large group and we would always move together (either to play sports or to go to functions or to see what nightlife was about).

The second nightclub was Whiskey Town. This nightclub was located at the top of the stairway next to Bargain Box and near to the Australian betting shop on Vitogo Parade. This nightclub had no escape route. The only way out was the stairwell which you had come up! This nightclub was a very rowdy place perhaps because it was in the town area. It was not open during the daytime. Whiskey Town was more often frequented by the 
villagers from the Lautoka area than Raymond Wong's nightclub was. The villagers came from Vitogo, Naviago, Vuda, and Namoli. It was easier than for the people from Vuda to come to Lautoka. We used to watch fights breaking out as a result of arguments which spiralled out of control. We would see fights but there was always something more to it than was obvious to people at the time. Sometimes fights would spill out on to Vitogo Parade. This nightclub was closed sometime after Club 21. It was easier for people to go to Whiskey Town because going to Raymond's meant a long walk back home to the village. Raymond's closed down first and then Club 21 and then Whiskey Town. Whiskey Town was at the center of the city and so it was the number one venue for the city's nightlife. This venue was the place where everyone went to for sports and social. It offered easy access to everybody. (Lautoka Club had already opened back then.)

Club 21 closed down before Whiskey Town. The location was opposite where Great Wall of China Restaurant is located now on the south side of Naviti Street (about halfway between Vidilo Street and Vakabale Street). I think it is upstairs from next to the Chinese phone shop called Dickson's. There was an indoor spiral staircase up to it which is still there today. This was a nightclub for the young working generation and the schoolchildren. By contrast, Whiskey Town was for the villagers and the local (indigenous) Fijian community. Club 21 had a very good atmosphere because all communities around Lautoka met there. This is where the young generation, which schooled in various places around Lautoka, came to meet up with each other in the evenings. I used to go there when I was in Ba Provincial Secondary School and later. Ba Provincial Secondary School was located at first where the present Housing Authority Office is today (beside Coronation Church). When I studied at this school it had already moved to its present location. Club 21 was very lax in checking whether you were of drinking age. You just had to look smart and act smart. There were fights there also. Sometimes old rivalries would lead to fights (for example, Waiyavi boys versus Topline boys). (Topline is a suburb on the outskirts of Lautoka.) This was a meeting place too during the eight-week school holidays. It used to be absolutely jam-packed. This nightclub was for all communities, but it was mainly patronized by the (indigenous) Fijians and the part-Europeans because the Indians tended to stick to themselves.

There were no Indian nightclubs then. The only place that the Indians went to occurred much later. It was opened just a few years back. That is the nightclub opposite the Sugar City Mall on Naviti Street. At that location there used to be the Galaxy Nightclub although it came later than the other nightclubs already mentioned. It only opened in the late-1970s. It was for the upper-class. It had a new type of dance-floor, lights underneath the floor, and the flickering balls which lit up the walls. Galaxy Nightclub was also mostly for the Fijians and the part-Europeans. It was later one of the busiest places of them all. In that central location the transport and the food were easily accessible, and this factor ensured its popularity. None of the restaurants open now in Lautoka were open back then. Tigers and Jolly Good have only been there for a short period of time (perhaps eight or nine years). I used to go to Lautoka Club but not all that often. I would go there for a drink or for special functions. Figure 4 shows the second-mentioned author Kieran James (left) with Jenny Leung at the Lautoka Club in 2014. Figure 5 depicts Henry Dyer Tuidraki (left) with the ex-Lautoka Blues soccer champion Wally Mausio also at the Lautoka Club in October of the same year (Figures $4 \& 5$ ).

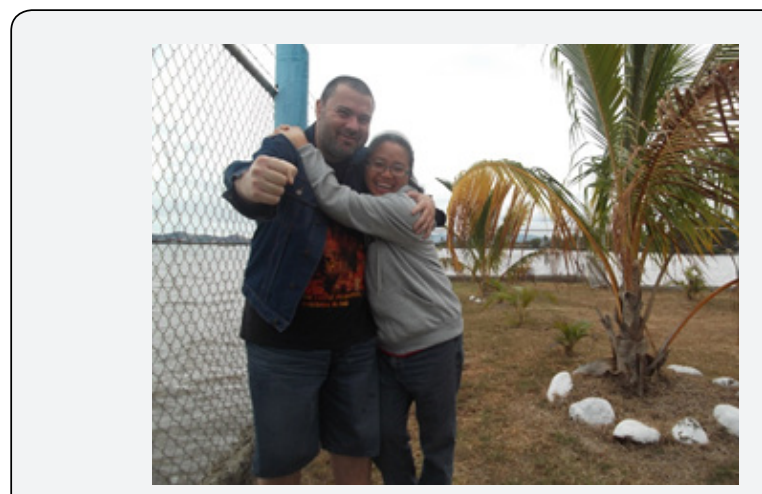

Figure 4: Kieran James (left) with Jenny Leung at the Lautoka Club in 2014.

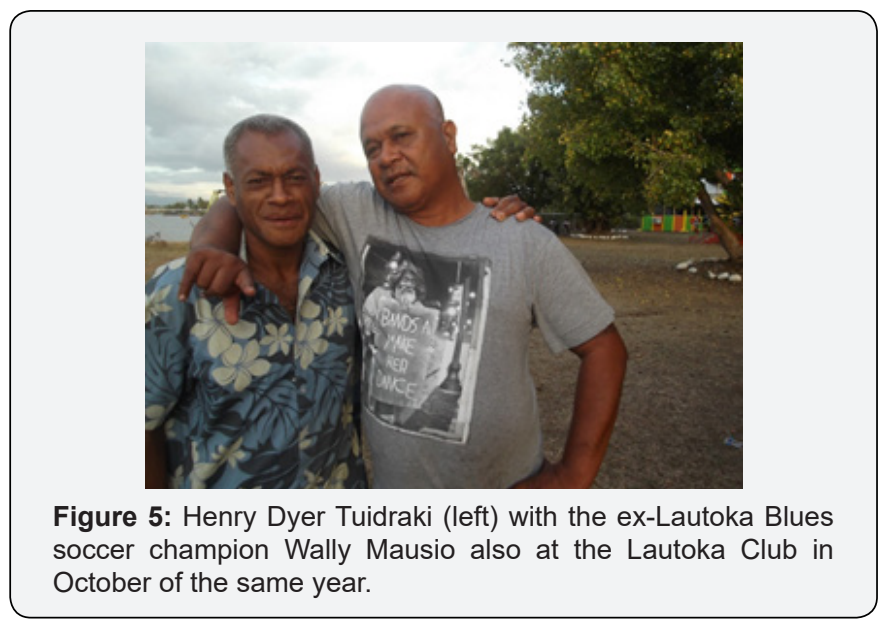

Sports and Social was another nightclub. At that time there were four nightclubs - Raymond's, Whiskey Town, Club 21, and Sports and Social. Galaxy was opened after Raymond's had closed down. Sports and Social Club was meant for the sports people of Lautoka. It was designed as a place for sportspeople to gather after matches. Sports and Social Club was located right beside Churchill Park. It was a building just to the right of the ticket booth at the Churchill Park main entrance. The building has since been demolished. It was where all the sportspeople and people from all sectors of life would meet together after the game and they would stay there until it was time to head home. We enjoyed meeting with the older generation of that time as they enjoyed us serving their beers and we would show respect to them. It gave them a touch of youth again. I remember old George Farrell, Alosi Johns and her husband David Johns (my uncle), Mrs. Millie Ah Tong, and Dr. Tuidraki. They were the 
regulars of the club during that time.

The Sports and Social Club was for the older working crowd. This was their pub. The younger generation sometimes would spill over and mingle with the older guys in the hope of receiving more beers because the older crowd, then as now, had more money. Sports and Social was where the younger generation would look to. It was a Nadi Club type of place but for the matured (indigenous) Fijians. It was patronized by government workers and private-sector workers. There were fights there sometimes when the older respected citizens were not around. The fights used to be extremely brutal because there were two empty streets and a whole playground to use for fights. You had to either fight or run for your life. We used to enjoy it. We would stand on the sugar-cane tramlines and watch. We would see people run or get knocked out. This club was open during the daytime as well. At one stage food was available but then that was stopped. People were very sad when this club closed. This was one of the saddest moments for Lautoka as it was owned by the locals. Even today, when I walk past that place, the memories keep coming back. It has been demolished for over ten years now and nothing has been done. I hope something can be done to resurrect it again. Club 21 changed its name to Great Wall of China. Now I see a restaurant in Naviti Street called Great Wall of China and I assume that they borrowed the name from the nightclub and/or that there were some connections through maternal links. The real Great Wall person was Raymond Wong (Patrick Wong's father) who also owned Club 21. Patrick Wong is in the tourism sector now. At one time he was managing one of the island resorts. I am really not sure where he is now.

Yang's Restaurant was owned by Alfred's family and Eddie Hin's restaurant was owned by, of course, Eddie Hin. He also had a lemonade / soft-drink company. There was a Chinese restaurant in Eddie Hin's building on the ground floor. I don't remember the name of the restaurant. There was a small milk bar there at the entrance to the restaurant. Many Fijian ladies were working there. This restaurant was open from the mid-1970s to the early1980s. It may even have existed as far back as the 1960s. I used to go there sometimes when I was a young schoolboy at Drasa Avenue School. (I left Drasa Avenue School in 1975.) I would have a milkshake there for 20 cents. You could sit inside the shop and have a milkshake. There was another milkshake restaurant owned by a Gujarati family called S.B. Maharaj. It was located near the Crown Theater, opposite the hockey grounds. I would meet with other schoolchildren there to have a milkshake. If I had 20 cents spare, I would stop there after school to have a milkshake with other Drasa Avenue schoolchildren. Today that milkshake would cost $\$ 3$ or more. The milkshake glass was very tall and very wide (perhaps nine inches by four inches). If I had 40 cents, I would have two. It would take until dinner to finish the two milkshakes. I used to enjoy sipping them very slowly. Things back then were very cheap.

Other nightclubs opened and closed but they did not have the longevity of the four clubs I have mentioned plus Galaxy
Nightclub. At one time there was a lack of nightlife in Lautoka. This was during the mid-1980s. The Sport and Social Club closed around 13 years ago. Before these nightclubs closed people from as far away as Ba, Tavua, and Vatukoula would come down to Lautoka because it was a city. They would enjoy the nightlife and spend the night there. That same crowd from the 1980s then gravitated to Nadi because Lautoka's nightlife had died. By this time, I also had moved to Nadi. The crowd would travel from Tavua to as far away as Nadi just to enjoy the nightlife. By that time (late-1980s) the tourism industry in Nadi had just started to boom. Lautoka now has a lot of nightlife again. The community has changed its approach to life. People have become friendlier amongst themselves. The present nightclub at Lautoka Hotel (now called Hunter's Inn) opened sometime during the early-1980s. It is called the Qara Vatu (in English: The Tomb). I remember going there. It was a different style to the other nightclubs. It had a different atmosphere as it appeared that you were really in a stone cave. There were lights, music, and a bar. We used to frequent this place only when we had money. Now the place is for anybody; before it was mostly for the young (indigenous Fijian) crowd from the nearby villages and communities. They all respected each other until it started getting a bit rowdy. My memory is strongest of the places I went to when I was very young which includes neither the Galaxy nor the Tomb.

There was also a nightclub which opened up in the Namoli Industrial Area (at the back of Namoli Village and close to the sea). This nightclub was also an attraction but unfortunately it did not last for long. This place was frequented mostly by the villagers and the other (indigenous) Fijians. It only lasted for around four or five years. It was great to have a night out there because you had a view of Bekana Island and the lights of the Lautoka Wharf; and you had the breeze. It was owned by a local. I do remember that beer was cheap there. I had a lot of friends there as I grew up in Lautoka. I used to really enjoy the nights there. This nightclub was opened much later, around the mid1990s. Sometimes I would visit because I would frequently go back and forth between Nadi and Lautoka. Since I grew up in Namoli Village I always retain a strong attachment to Lautoka. I have my mother's family residing there too.

Section Three - The Sea God Visits Namoli Village / Basketball at the Chinese School, by Henry Dyer Tuidraki. This section discusses the visit of the Sea God to Namoli Village, Lautoka City, Fiji Islands, as recalled by the ex-Nadi and Fiji soccer champion Henry Dyer Tuidraki in conversation with Kieran James on April 23, 2015. There is also a discussion about the places which traditional mythology and Christianity inhabit in the minds and hearts of the average Fijian villager today; and how some but not all villagers attempt to integrate these two belief systems, whilst others cling to Christianity and reject earlier traditions.

The players who made it to the Fiji team from basketball came from Namoli Village and most of them succeeded because 
of their early years at the Chinese School's basketball court. (The Chinese School is located opposite Namoli Village on the other side of Namoli Avenue.) They played with the Chinese basketball team from Lautoka. Then they formed a team of their own. Players such as Apolosi Tora made it into the Fiji team. Of the ladies there was Kesaia and Mere Satala. They made the team because the Chinese community was very small, and the Chinese could not make up two teams for training. So, the village boys would make up the numbers for the second team. The village ladies got involved because of their interest but the Chinese ladies did not participate. Therefore, the Chinese School basketball court made some impact into the lives of the Namoli youth at one stage back then. Their interest was very high. We used to stand on the side-lines near the seaside watching until it was so dark, we could not see the ball. It was just a wire-fence at that time. They let us in because we were also contributing to guarding the school. Now there is a brick wall there but then it was just wire. We played until dark or until you could not see the ball. If it was a full moon, I remember we played for much longer. I played just for fun but there were much better players than me who understood the game more and had the rhythm for the game. The first basketball team started way before the 1970s. I started using the court as a child in the early-1970s.

The Chinese School is one of the oldest schools in Lautoka. Back then for a (non-Indian) local to school in the Chinese School it was an unusual event. We knew the culture of the Chinese education system there. Behind the Chinese School, where the minibus stand is located today (on Tukani Street), there were bushes and a wild guava plantation. Figure 6 shows two young children inside the Chinese School compound in Lautoka City in more recent times. (The author's daughter Nicoleta James is on the right.) The basketball court, which still exists today, is located directly behind the cameraperson.

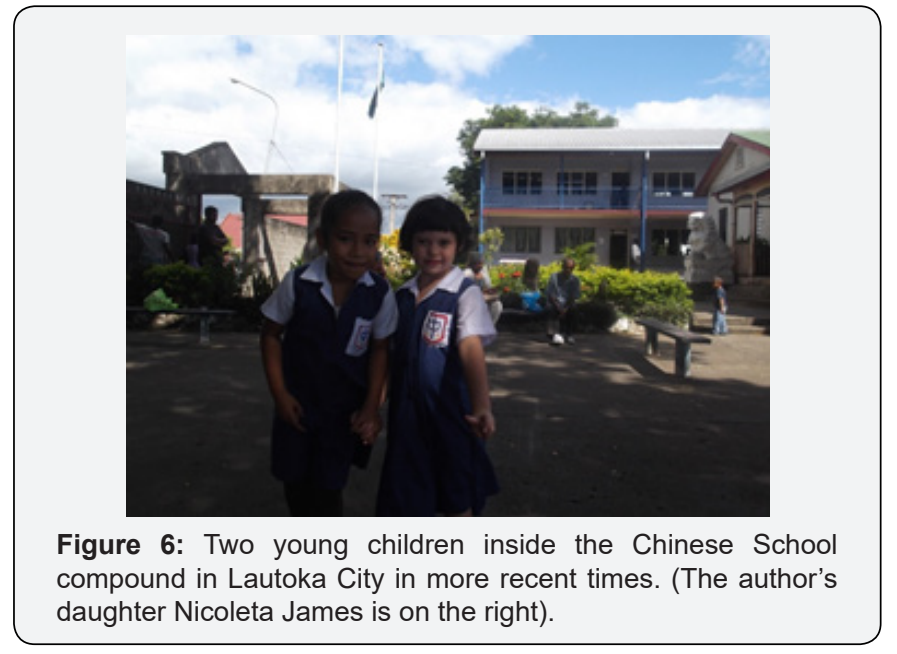

Fiji has a long history of the sea gods and as kids we knew about this because, being brought up by the sea at Namoli Village, there was this young woman (just a little older than us) who, at twilight of the evening, was possessed by the sea god who appeared on land. He was the sea god of the low tide. We had to take this young woman to her family. They asked the sea god to please leave her alone. They did the Fijian ceremony and asked the sea god: "Why are you giving the young child trouble?" He answered back through the young woman saying: "You are all making too much noise at the place where I surfaced [i.e. the basketball court at the Chinese School]." I experienced this myself. The sea god's name was Rateciyavi (meaning "the twilight low tide.") Twilight was the time when he came up to the surface.

Straight after this incident the Chinese School became empty at that time of the evening. The belief was really high, and sports training used to be affected. This continued until such a time as some stronger boys came through who said not to believe in it and to carry on training regardless. The girl was set free and the devil disappeared. The sea god used to attract the women more. He used to choose the pretty women in particular as his victims. I remember that Namoli Village was full of belief because many strange things occurred there.

Sometimes when you are a young teenager (aged 14 to 16 years) you want to explore what life is all about. We used to walk around the streets of Lautoka and we were open to all kinds of mischief. However, belief in the ancestral gods was always there in the back of our minds.

The Fijians believe that, before Christianity came, they had their own ancestral gods. Those gods had power and gave them strength. The Christians today (the orthodox ones) treat the Fijian ancestral gods as demons. However, the real native Taukei person (the hardcore villager) still believes that the ancestral gods exist even though he goes to church. He can mix them with the Christian God in his understanding of the world. However, the (indigenous) Fijians who are really into Christian belief opt to stay away from mixing the two gods. They can mix the two, but they opt not to because it is a very dangerous thing. They know that it is a demon. While walking in the streets of Lautoka we would be talking about all the collective stories from our individual families. We would be talking about different episodes of the gods. It used to be really scary while walking the streets of Lautoka. There were very few lights on the streets then. When we reached the villages, we used to just split up and run to our individual houses. We were afraid that the demons were waiting for us. Sometimes we would crash into the front door.

Talking about the ancestral gods, I had to spend one of my school holidays with my grandma's household at Tukuvuci. This is close to the Fiji Bitter beer factory. At this same time, as soon as it was dark, my grand-mum (the mother of the Ratudradra brothers) would tell her grandchildren to run up a small hill with a kerosene lantern for 40 meters. She would tell us to run down with the lantern again. She would say: "He's there." We would say: "Who's there?" She would tell us: "Look towards the hills" (Tavakubu Hills and beyond). Up above the pine trees we would see a light floating over the ridges and the trees in the dark. She would tell us: "There, you see he is playing with us." As a child, 
I ran up and down that small hill and played with the ancestral gods. I don't know whether the children today will see what I saw then with my own eyes. We children living in that generation at that time were quite fortunate to see a lot of things from the ancient past. We could see it with our eyes. I don't know whether people can see that today or possibly not because Christianity has seeped into every house today. The upbringing in those days was very special. You were taught to obey and to be respectful. You were taught to dress to the occasion. You were taught to always say the right things and not to be rude or offensive. We were taught to respect the older menfolk (the uncles) as they were the next in line to take over in the house. The youngest uncle was respected in the same way that the eldest uncle was. The (indigenous) Fijian protocol was indeed something else.

\section{References}

1. Prasad M (2008) Celebrating 70 Years of Football, 1938-2008 (Suva: Fiji Football Association).

2. New Zealand International Matches Details: 1980-1989.

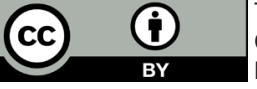

This work is licensed under Creative Commons Attribution 4.0 Licens DOI: 10.19080/JPFMTS.2019.06.555686

\section{Your next submission with Juniper Publishers} will reach you the below assets

- Quality Editorial service

- Swift Peer Review

- Reprints availability

- E-prints Service

- Manuscript Podcast for convenient understanding

- Global attainment for your research

- Manuscript accessibility in different formats ( Pdf, E-pub, Full Text, Audio)

- Unceasing customer service

Track the below URL for one-step submission https://juniperpublishers.com/online-submission.php 